\section{FORAGE-SAMPLE DRYER}

\section{J. L. Schuster and W. B. Duke}

Southern Forest Experiment Station, Forest Service, U.S. Department of Agriculture, Nacogdoches, Texas.

An inexpensive dryer for forage samples can be constructed by connecting a forced-air heating unit through sheet-metal ducts to an insulated drying chamber. Figure 1 shows the general arrangement. The dryer was designed at the U.S. Forest Service's Wildlife Habitat and Silviculture Laboratory ${ }^{1}$, Nacogdoches, Texas.

An upright central heating unit with an input rating of 80 ,000 BTU's supplies the heat. Its squirrel cage blower, driven by a $1 / 3$-hp. motor, moves approximately 1,200 cubic feet of air per minute. Temperatures inside the drying chamber are automatically regulated by a thermostat adjustable in the range between 28 and $82^{\circ} \mathrm{C}$.

The drying chamber illustrated was obtained from Army surplus. It is a 150 cubic-foot walk-in refrigerator box 61 inches high, 62 inches wide, and 74 inches deep on the inside. Removable shelves made of expanded metal and $1 / 2$ - by $1 / 2-$ by $1 / 8$-inch angle iron are attached to each wall (Figure 2). A false ceiling inside the box creates a 3 -inch plenum. Hot air is vented into the chamber through twenty-four 2-inch holes spaced in four rows from the rear to the front of the false ceiling. The return duct contains three dampers: (1) the fresh air intake, (2) the moist air outlet, and (3) the central damper. With the central damper closed and the other two open, outside air is heated and forced through the system. To recirculate the same air the central damper is opened and the

1Maintained in cooperation with Stephen F. Austin State College. others closed. Any variation in degree of circulation can be attained by adjusting the dampers. Installed, the forage-sample dryer is approximately 6 feet high, 6 feet wide, and 13 feet long.

\section{Materials and Construction Costs}

The refrigerator box was available without cost. Materials for the false ceiling and shelves cost $\$ 56$ and were installed in 5 mandays. The heating unit cost $\$ 179$, the thermostat $\$ 30$, and the sheet metal for ducting \$31. Installation of heating unit and construction of ducts required 6 man-days.

The drying chamber is not included in these costs, but ma- terials for an insulated chamber of plywood construction should cost less than $\$ 115$. Newton et al. (1961) constructed a much larger (1,152 cubic-foot) chamber of $1 / 4$-inch plywood and rock wool insulation for $\$ 523$. Neff's (1963) drying oven, converted from a household refrigerator for $\$ 40$, has a limited capacity.

\section{Operation and Drying Efficiencies}

The dryer has been used successfully for 2 years. As many as 240 forage samples have been dried in one operation. With this capacity, several days' clippings may be accumulated for weighing, or large volumes dried promptly to avoid dry-matter loss from respiration or enzy-

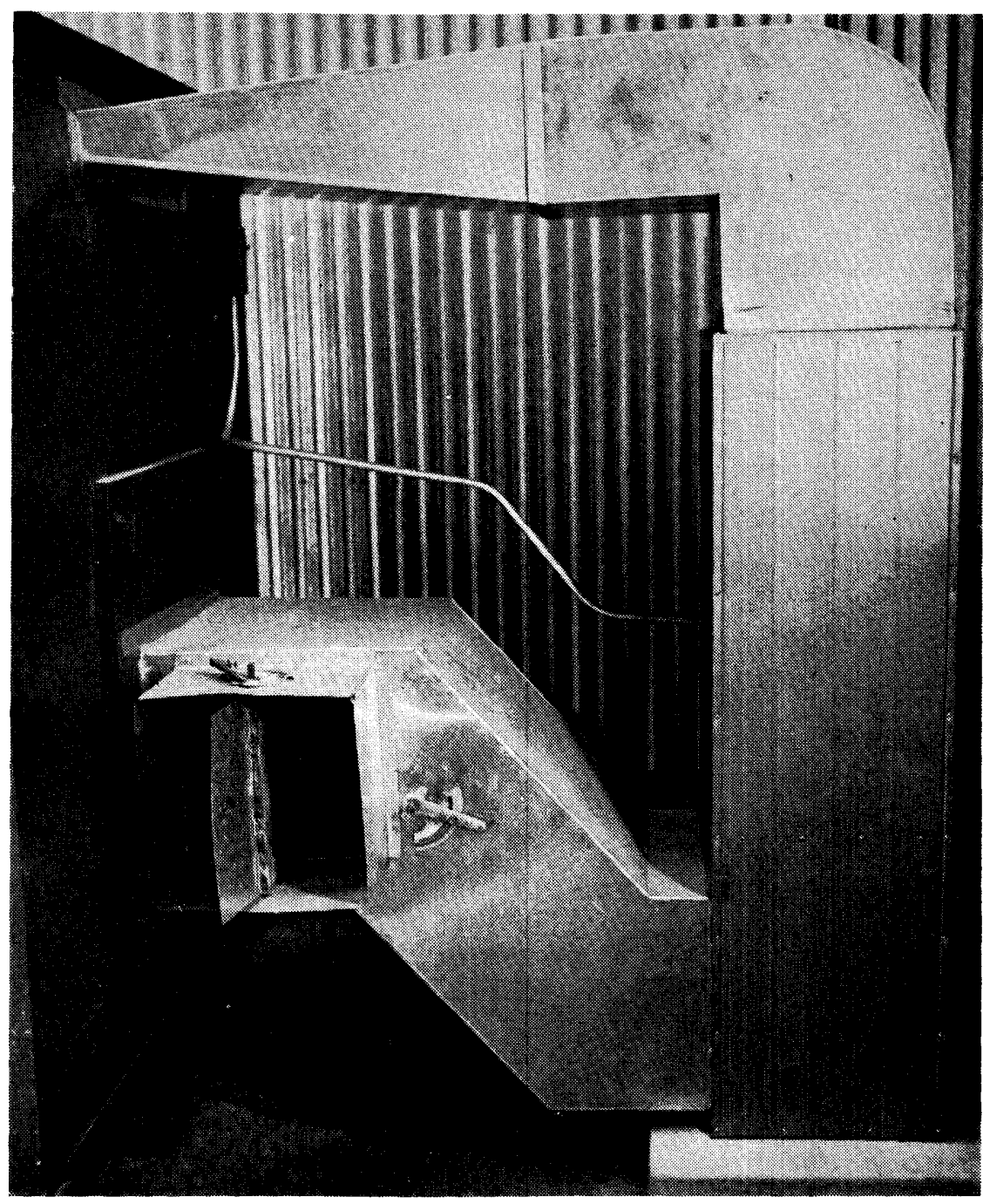

Figure 1. Side view of forage dryer. $\Lambda$ ir heated in gas-fircd unit at right is blown through top duct into drying chamber. It returns through the large lower duct, which contains dampers that permit either exhausting the moist air or recirculating it. 
matic action (Raymond and Harris, 1954).

In one trial, seventy-two 200gram samples of browse and grass were dried at $60^{\circ} \mathrm{C}$. The dampers were adjusted so that approximately half the heated air was recirculated. The temperature in the center of the drying chamber ranged from a low of $51^{\circ}$ to a high of $68^{\circ} \mathrm{C}$. Average lapse between low and high temperatures was $10 \mathrm{~min}$ utes. Drying rates varied among species, but all samples had lost at least 99 percent of their moisture in 42 hours, and were dry in 48 hours. (Moisture content was based on difference between initial green weight and final constant weight at $70^{\circ}$ C.) Samples on the top shelf had lost slightly more moisture at 24 hours than those on the lower shelves, but the differences were not statistically significant.

In a second test the dryer was

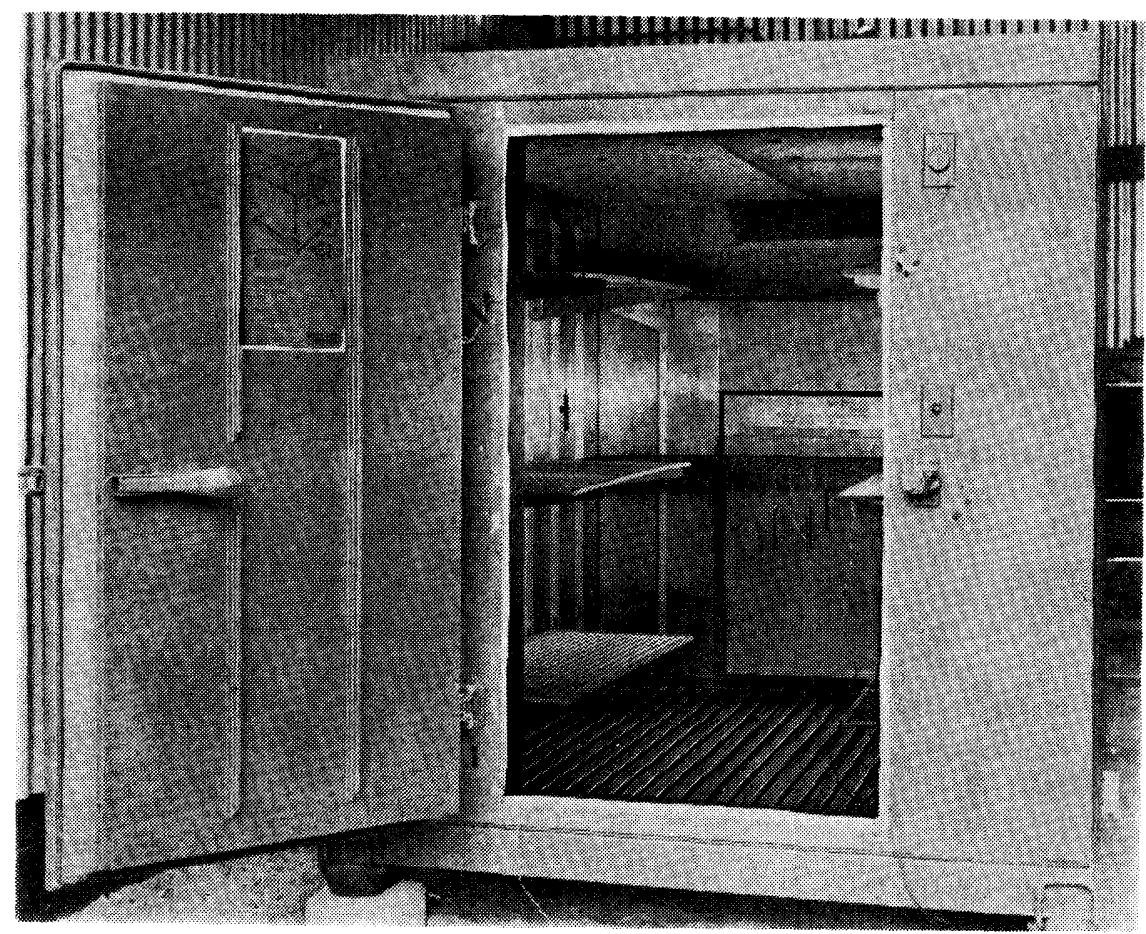

Figure 2. Drying chamber. Heated air enters through holes in false ceiling. Exhaust air outlet is at base of panel at back. The wires lead to thermocouples used in tests.
Table 1. Results of drying-efficiency tests with forage-sample dryer operating at $70^{\circ} \mathrm{C}$.

\begin{tabular}{|c|c|c|c|c|c|}
\hline \multirow{2}{*}{ Species } & \multirow{2}{*}{ Samples } & Green & \multicolumn{3}{|c|}{ Moisture $\operatorname{loss}^{1}$} \\
\hline & & weight & At $24 \mathrm{~h}$ & 42 hrs. & Total \\
\hline & No. & Grams & Pct. & Pct. & Gran \\
\hline American beautyberry & 18 & 3 & 99.8 & 100.0 & 1,973 \\
\hline Dogwood & 18 & 3,208 & 99.4 & 100.0 & 1,853 \\
\hline Fringetree & 18 & 3,251 & 99.9 & 100.0 & 1,756 \\
\hline Johnson grass & 54 & 9,393 & 100.0 & 100.0 & 6,457 \\
\hline Total & 108 & 19,135 & & & 12,039 \\
\hline
\end{tabular}

${ }^{1}$ Based on constant weight at $70^{\circ} \mathrm{C}$.

loaded with 108 samples of forage (175 grams each) and operated at $70^{\circ} \mathrm{C}$. with complete air recirculation. Temperatures ranged from 65 to $75^{\circ} \mathrm{C}$., with an average time of 10 minutes between high and low temperatures. Eighteen samples each of dogwood (Cornus florida L.) fringetree (Chionanthus virginicus L.), and American beautyberry (Callicarpa americana L.) and 54 samples of Johnson grass (Sorghum halepense (L.) Pers.)

were distributed at random throughout the drying chamber. After 24 hours Johnson grass was at a constant weight, while dogwood, fringetree, and American beautyberry had lost more than 99 percent of their moisture (Table 1). All samples were at a constant weight by 42 hours.

These tests show that the dryer is capable of bringing forage samples to a constant weight in 48 hours at $60^{\circ} \mathrm{C}$. or in 42 hours at $70^{\circ}$. In practice, samples are collected in 16-pound paper bags, which are stapled shut without folding and stacked upright on the shelves. All samples are dried for at least 42 hours at $70^{\circ} \mathrm{C}$. to assure constant weights.

The makers of the heating unit recommend against higher operating temperatures, because of the possibility that the furnace's heat exchanger will fail if the temperature of the air leaving the furnace exceeds $93^{\circ} \mathrm{C}$.

\section{Literature Cited}

NeFF, D. J. 1963. An inexpensive drying oven for forage samples. Jour. Range Mangt. 16: 274-275.

Newton, J. P., Futral, J. G., CraigIMILES, J. P., AND DOBSON, J. W., JR. 1961. A forage dryer for experimental research. Ga. Expt. Sta. Mimeo. Series N.S. 114, 12 pp.

RAYMOND, W. F., and HarRis, C. E. 1954. The laboratory drying of herbage and faeces, and dry matter losses possible during drying. Jour. British Grassland Soc. 9: 119-130. 